\title{
Adana İlindeki Mısır Üretim Alanlarında Zararlı Mısır Kurtlarının (Lepidoptera: Crambidae, Noctuidae) Yaygınlık Durumunun Belirlenmesi
}

\section{ÖZ}

\author{
Serkan PEHLIVAN ${ }^{*}$, Ekrem ATAKAN $^{1}$
}

Adana İlinde mısır kurtlarının yaygınlığını belirlemek amacıyla, 2020 yılında birinci ve ikinci ürün mısırlarda sörvey çalışmaları yapılmıştır. Birinci ürün mısırlarda bulaşık bitki oranının \%17.8351.94, ikinci ürün mısırlarda ise \%5.18-32.36 arasında değiştiği saptanmıştır. Bitkilerin vejetatif döneminde en yaygın tür $C$. partellus olmuştur. Püskül+koçan döneminde ise birinci ürün misırlarda $C$. partellus en yaygın tür olurken, ikinci ürün mısırlarda, $O$. nubilalis ana tür olmuştur. Sesamia nonagrioides ise tüm örnekleme yörelerinde çok düşük oranlarda kaydedilmiştir. Adana İlinde yapılan bu çalışma ile $C$. partellus'un birinci ürün mısırlarda ana zararlı tür olduğu, ikinci ürün mısırlarda da erken dönemde zararlı olduğu belirlenmiştir.

Anahtar kelimeler: Mısır, Chilo partellus, Ostrinia nubilalis, Sesamia nonagrioides, yaygınlık, Adana

\section{Determination of Distribution of Corn Stem Borers in Maize Production Areas of Adana Province}

\section{ABSTRACT}

The survey studies were carried out on the first and second crop maize areas in Adana to determine the distribution of the corn stem borers. It has been determined that the damaged plant ratio due to the stem borers was ranged between 17.83 and $51.94 \%$ in the first crop maize and varied from 5.18 to $32.36 \%$ in the second crop maize. C. partellus was the most common pest insect species in the vegetative period of both first and second crop maize. In the tassel + cob period, $C$. partellus was the most common species in the first crop maize, while $O$. nubilalis was the dominant species in second crop maize. Sesamia nonagrioides was recorded in very low rates in all sampling locations. With this study, it was determined that $C$. partellus was the main pest species in the first crop corn, and also it can cause damage in the second crop maize in the early growing season.

Keywords: Maize, Chilo partellus, Ostrinia nubilalis, Sesamia nonagrioides, distribution, Adana

ORCID ID (Yazar sırasına göre)

0000-0002-9444-7457, 0000-0001-7352-4815

Yayın Kuruluna Geliş Tarihi: 25.01.2021

Kabul Tarihi: 05.03.2021

${ }^{1}$ Çukurova Üniversitesi, Ziraat Fakültesi, Bitki Koruma Bölümü, Sarıçam, Adana, Türkiye

*E-posta: spehlivan@cu.edu.tr 


\section{Adana İlindeki Mısır Üretim Alanlarında Zararlı Mısır Kurtlarının (Lepidoptera: Crambidae, Noctuidae) Yaygınlık Durumunun Belirlenmesi}

\section{Giriș}

Anavatanı Orta Amerika olan ve Dünya'da buğday ve çeltikten sonra tarımı yapılan en önemli ürün olan misır (Zea mays L.), Buğdaygiller (Gramineae=Poaceae) familyasında yer almaktadır (Purseglove, 1992; Sandhu ve ark., 2007; Shah ve ark. 2016). Dünya genelinde yıllık dane misır üretimi 1.1 milyar ton iken, ABD y1llik 347 milyon ton, Çin 260 milyon ton ve Brazilya ise yaklaşık 101 milyon tonluk bir üretim ile misır üretimi yapan ülkeler arasında ilk siralarda bulunmaktadırlar (FAO, 2019). Ülkemiz de ise yaklaşık 6 milyon tonluk misır üretim gerçekleştirilirken, bu üretiminin \% 19'luk kısmı Çukurova'dan sağlanmaktadır. Adana İli ise yaklaşık 700 bin tonluk mısır üretimi ile ülke ekonomisine katkıda bulunmaktadır (TUIK, 2019). İnsan beslenmesinde oldukça önemli bir yeri olan misır, 1950'den sonra tarım sektöründe meydana gelen teknolojik gelişmelerle birlikte endüstriyel alanlarda da yaygın olarak kullanılmaya başlanmıştır. Son yıllarda artan teşvik ile birlikte Adana'da misır üretimi hem birinci ürün olarak, hem de buğday üretimini takiben ikinci ürün olarak yapılmaktadır.

Yapılan bu üretimin yanında mısır alanlarında önemli kayıplar meydana getiren pek çok etmen arasinda misır kurtları ana zararlılar olarak bilinmektedirler. Çukurova Bölgesi'nde özellikle ikinci ürün misır üretiminde karşılaşılan en önemli zararlılar Misırkurdu, Ostrinia nubilalis Hübner (Lepidoptera: Crambidae) ve Misır koçankurdu, Sesamia nonagrioides Lefebvre (Lepidopeta: Noctuidae) olmasına rağmen (Kayıpınar ve Kornoşor, 1992; Sertkaya ve Kornoşor, 2000), Adana, Osmaniye ve Hatay illerinde ilk defa 2014 yılında tespit edilen Benekli misır sapkurdu, Chilo partellus Swinhoe (Lepidoptera: Crambidae) (Sertkaya ve ark., 2014), özellikle birinci ürün mısırlarda ciddi zararı nedeniyle son yıllarda önemli verim kayılarına neden olmaktadır (Achiri ve ark., 2020a). Ayn yıllarda Hatay'da zararlının biyolojik mücadele imkanlarının araştırıldığ 1 çalışmada, iki yerel doğal düşman, Trichogramma brassicae Bezdenko (Hymenoptera: Trichogrammatidae) ve Telenomus busseolae (Gahan) (Hymenoptera: Platygasteridae) C. partellus'un yumurta parazitoitleri olarak ilk kez kaydedilmiştir (Can Cengiz ve ark., 2016). Adana'da yapılan bir çalışmada da Trichogramma evanescens Westwood (Hymenoptera: Trichogrammatidae) $C$. partellus'un yumurtalarını parazitlediği ilk kez bildirilmiştir (Achiri ve ark., 2020b).

Çukurova'da mısır alanlarında C. partellus bireylerinin mayıs ayının ilk günlerinde zarar yapmaya başladığı (Achiri ve ark., 2020a), $O$. nubilalis ve $S$. nonagrioides' in ise ilk erginlerinin temmuz ayında misir tarlalarında görüldüğü bildirilmiştir (Sertkaya, 1993; Kayapınar, 1988; Kurtuluş, 2016). Hindistan orjinli olan C. partellus'un Afrika kitasinın sıcak bölgelerinde 1989 yılından sonra hizla yayıldığ1 (Kfir, 1993; Guofa ve ark., 2001; Yonow ve ark., 2017), Akdeniz ülkelerinde ise 2013 yılından sonra yayılmaya başladığı bildirilmektedir (Ben-Yakir ve ark., 2013; Sertkaya ve ark., 2014). Bu yayılma özelliğinden dolayı C. partellus'un bazı Afrika ülkelerinde yerli misır kurdu türlerini baskıladığ1 ve mısırda ana zararlı konumuna geldiği görülmüştür (Kfir, 1997; Polaszek, 1998). Çukurova'da misır kurtları ile ilgili pek çok çalışma yapılmış olmasına rağmen, son yıllarda özellikle $C$. partellus'un ülkemizde ilk kayıtından sonra özellikle üretici tarlalarında tür kompozisyonundaki yeri ve zarar durumu yeterince bilinmemektedir. Bu nedenle istilac1 tür, C. partellus ile diğer misır kurtlarının Çukurova'da birinci ve ikinci ürün mısırlarda bulunma oranları ve bitkilerin misır kurtları açısından bulaşıklılık durumları bu çalışmayla incelenmiştir.

\section{Materyal ve Yöntem \\ Adana İlinde Misır Kurtlarının Yaygınlığının Belirlenmesi}

Adana ilinde 2020 y1lında mısır üretiminin yaygın bir şekilde yapıldığ 1 Balcalı, Kozan, Karataş, Sarıçam ve Yüreğir yörelerinde birinci ürün mısırlarda nisan ayının başından itibaren; Balcalı, Ceyhan, Kozan, Sarıçam ve Yüreğir yörelerinde ise ikinci ürün misırlarda temmuz ayının başından itibaren 15 günlük aralıklarla 


\section{Adana İlindeki Mısır Üretim Alanlarında Zararı Mısır Kurtlarının (Lepidoptera: Crambidae, Noctuidae) Yaygınlık Durumunun Belirlenmesi}

sörvey çalışmaları gerçekleştirilmiştir. Her mısır tarlasında araziyi temsil edecek şekilde, tarlanın 5 farklı noktasında tesadüfü olarak seçilen 10 bitkinin kök hariç diğer kısımları kontrol edilerek tarlanın misır kurtları yönünden bulaşıklık durumları (\% bulaşıklılık oranları) saptanmıştır. Bulaşık bitki kısımları arazide kesilmiş ve tespit edilen ergin öncesi dönemler, (yumurta, larva ve pupalar) alınarak kültür kaplarıyla birlikte laboratuvara getirilmiştir. Ergin bireyler elde edildikten sonra zararlıların tür teşhisleri yapılmış ve sayılarak kaydedilmişlerdir. Örnekleme yapılan alanlarda ayrıca bitkilerin fenolojik dönemleri de kayit edilerek zararlilar ile ilişkilendirilmiştir.

\section{Verilerin Değerlendirilmesi}

Hem birinci ürün hem de ikinci ürün mısırlarda tüm sezon boyunca örneklenen her misir tarlasından toplanan bireylerin en yüksek sayıda olduğu haftadaki ortalamaları alınarak misır bitkilerinin genel bulaşıklılık oranları saptanmıştır. Her örnekleme yöresinde bitkilerin vejetatif ve püskül-koçan döneminde toplanan bireylerin ortalamaları alınarak, bitkilerin fizyolojik dönemine göre bulaşık bitki oranları ve ayrica toplanan misir kurtlarının oranları da belirlenmiştir. Tüm hesaplamalar Microsoft Excell (2010) programı kullanılarak yapılmıştır.

\section{Bulgular ve Tartışma \\ Adana İlinde Birinci Ürün Mısırlarda Zararlı Mısır Kurtlarının Genel Durumu}

Mısır, dünyada buğday ve çeltikten sonra en fazla tarımı yapılan tahıl bitkisidir. Sesamia nonagrioides, $O$. nubilalis ve $C$. partellus misırda ekonomik anlamda kayıplara sebep olan en önemli Lepidoptera türleridir. $\mathrm{Bu}$ zararlilardan $\quad$ C. partellus'un Balcalı yöresindeki mısır tarlasında en yaygın tür olduğu ve bitkilerde erken dönemden başlayarak ciddi zararlara neden olduğu saptanmıştır (Achiri ve ark., 2020a). Bu çalışma ile 2020 y1lında Adana ilinde birinci ve ikinci ürün misır üretim alanlarında 5 farklı yörede ticari olarak üretimi yapılan birer adet misır tarlasında misır kurtlarının yaygınlıkları ve mısır bitkilerinin bu zararlı türlerce bulaşıklılık durumları incelenmiştir.

Adana İli mısır üretim alanlarında birinci ürün misırlarda yapılan örneklemeler sonucunda, tüm türler birlikte değerlendirildiğinde misır kurtları ile bulaşık bitki oranları, Balcalı ve Kozan yörelerinde sirasiyla \%51.94 ve \%45.74 ile en yüksek olmuştur. Yüreğir yöresi ise $\% 17.83$ 'lük oran ile bulaşık bitki oranının en düşük olduğu yöre olurken, diğer yörelerde bu oran \%28-30 arasında değişmiştir (Şekil 1).

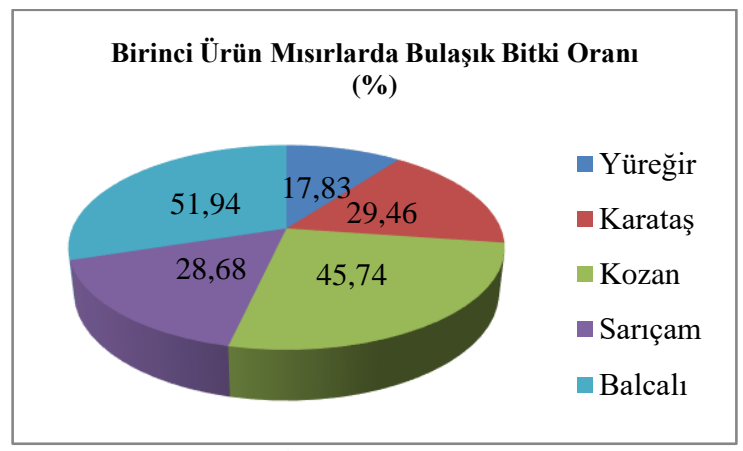

Şekil 1. Adana İli'nde birinci ürün mısırlarda yörelere göre bulaşık bitki oranları (\%).

Bitkilerin fenolojik dönemleri zararlı böceklerin bitkiler üzerinde zarar meydana getirebilmeleri açısından önem arz etmektedir. Misırlarda zarar meydana getiren Lepidoptera takımına ait böceklerin bazıları toprak altı aksamlarında beslenirken (Güllü ve ark., 2017), birçoğu özellikle mısır kurtları yeşil aksam üzerinde zarar meydana getirmektedirler (Sertkaya ve ark., 2004; Sertkaya ve Bayram, 2005; Sertkaya ve ark., 2014). Misir kurtları bitkilerin hem vejetatif hem de generatif organlarda önemli zararlar meydana getirmeleri nedeniyle bu zararlılar arasında ön plana çıkmaktadırlar. Bu misır kurtlarının nisan ayından itibaren doğada aktif olduğu ve özellikle mısırların 4-6 yapraklı döneminden itibaren zarar yapmaya başladığı bildirilmektedir (Sertkaya ve ark., 2004: Sertkaya ve Bayram, 2005; Sertkaya ve ark., 2014; Achiri ve ark., 2020a).

$\mathrm{Bu}$ amaçla, bitkilerin vejetatif ve püskül+koçan dönemlerine göre bulaşık bitki oranları incelendiğinde, Balcalı ve Yüreğir yörelerinde her iki dönemde de bulaşık bitki oranlarının benzer olduğu, Kozan yöresinde vejetatif 


\section{Adana İlindeki Mısır Üretim Alanlarında Zararlı Mısır Kurtlarının (Lepidoptera: Crambidae, Noctuidae) Yaygınlık Durumunun Belirlenmesi}

dönemde, Karataş ve Sarıçam yörelerinde ise püskül+koçan dönemlerinde bulaş1k bitki oranlarının daha yüksek olduğu bulunmuștur (Şekil 2).

Chilo partellus'un ülkemizde tespit edilmesiyle birlikte, Çukurova Bölgesi'nde hem birinci ürün hem de ikinci ürün misırlarda hızlı bir şekilde yayıldığı ve zarar vermeye başladığ 1 bildirilmiștir (Sertkaya ve ark., 2014; Öztemiz ve Akmeşe, 2018; Achiri ve ark., 2020a). Bu çalıșma ile birinci ürün misırlarda yapılan örneklemeler sonucunda, vejetatif dönemde $C$. partellus'un Kozan yöresinde \%93.27, diğer örnekleme yörelerinde ise \%100'lük bulaşma oranı ile en yaygın tür olduğu saptanmıştır (Şekil 3).

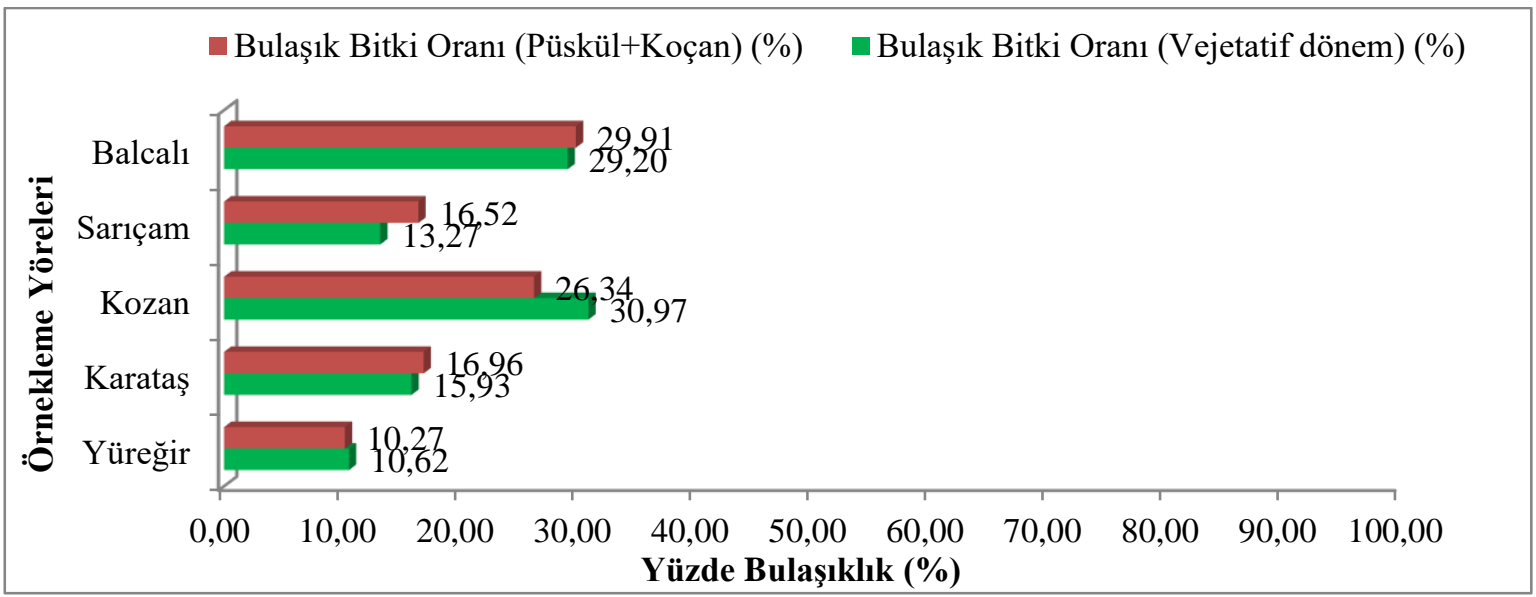

Şekil 2. Adana ilinde birinci ürün mısırlarda yörelere ve bitki gelişme dönemlerine göre bulaşık bitki oranları $(\%)$.

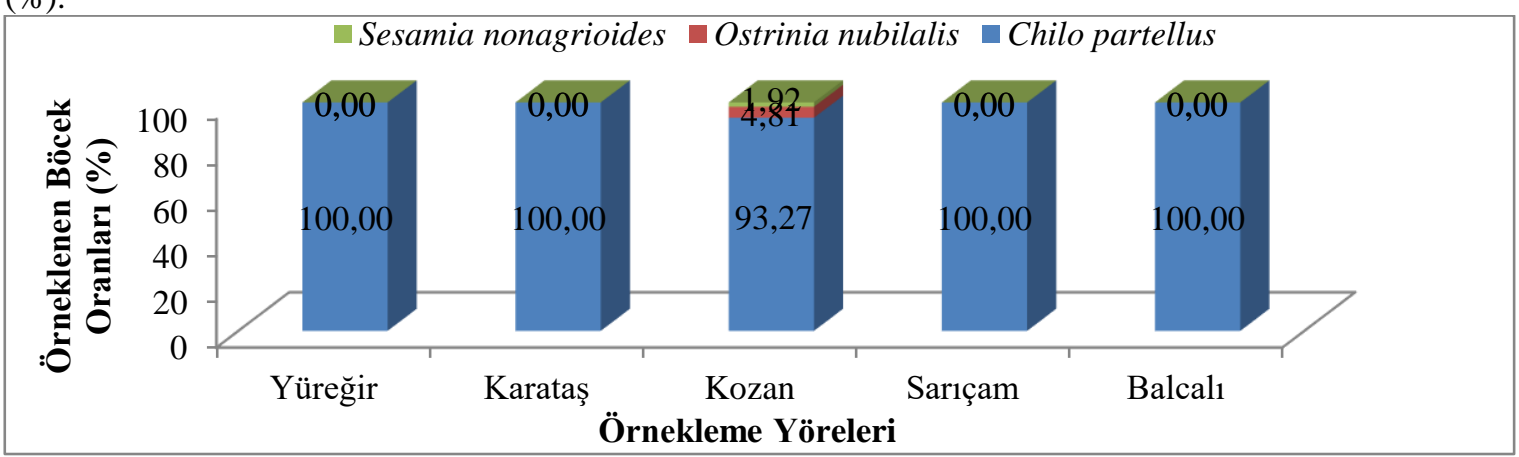

Şekil 3. Adana ilinde birinci ürün mısırlarda bitkilerin vejetatif dönemlerinde mısır kurtlarının toplam popülasyon içinde bulunma oranları (\%). 


\section{Adana İlindeki Mısır Üretim Alanlarında Zararı Mısır Kurtlarının (Lepidoptera: Crambidae, Noctuidae) Yaygınlık Durumunun Belirlenmesi}

Birinci ürün mısırlarda bitkilerin püskül-koçan dönemine geçmeleriyle birlikte, $O$. nubilalis ve $\mathrm{S}$. nonagrioides'in oranlarında bir artıș gözlense de, $C$. partellus'un sırasılyla Sarıçam, Kozan, Karataş, Balcalı ve Yüreğir yörelerinde $\% 89.09, \% 96.43, \% 98.73, \% 100$ ve $\% 100$ 'lük bulunma oranlarıla ana zararlı tür olduğu saptanmıştır (Şekil 4).

Achiri ve ark. (2020a), Balcalı (Adana) yöresinde özellikle birinci ürün misırlarda, C. partellus'un nisan ayının ortasından itibaren mısır alanlarına göç ettiğini ve bu zararlının en yaygın misır kurdu olduğunu bildirmiştir. Çukurova'da $O$. nubilalis'in ilk ergin uçuşlarının nisan ayında başladığı, en yüksek popülasyonun ağustos ayında gözlemlendiği ve yılda 4 döl verdiği bildirilmiştir (Kayapınar, 1988). Sesamia nonagrioides' in ise ilk erginlerinin yine nisan ayında uçmaya başladığı, en yüksek popülasyon yoğunluğuna ekim ayında ulaştığı ve iklim koşullarına bağlı olarak yılda 4-5 döl verdiği saptanmıştır
(Sertkaya, 1993). Ayrıca düşük popülasyon yoğunluklarından dolayı bu iki misır kurdunun birinci ürün olarak ekilen misırlarda zarar meydana getirmedikleri bildirilmektedir (Kornoşor ve ark., 1995, Özpınar ve Kornoşor, 1997). Chilo partellus'un 1989 yılindan sonra Afrika kıtasının sıcak bölgelerinde yayıldığı (Kfir, 1993; Guofa ve ark., 2001; Yonow ve ark., 2017), 2013 yılindan sonra ise Akdeniz ülkelerinde yayılmaya başladığı bildirilmektedir (Ben-Yakir ve ark., 2013; Sertkaya ve ark., 2014). Bu yayılma özelliğinden dolayı $C$. partellus'un bazı Afrika ülkelerinde yerli mısır kurdu türlerini baskıladığ 1 ve mısır alanlarında ana zararlı konumuna geldiği görülmüştür (Kfir, 1997; Polaszek, 1998). Bu çalışmadan elde edilen sonuçlar, $C$. partellus'un birinci ürün misırlarda ana zararlı tür olduğunu gösterebilir. Bu bağlamda ilerleyen y1llarda da misır üretim alanlarında bu zararlı tür ile diğer misır kurtlarının popülasyonunun takip edilmesinde yarar görülmektedir.

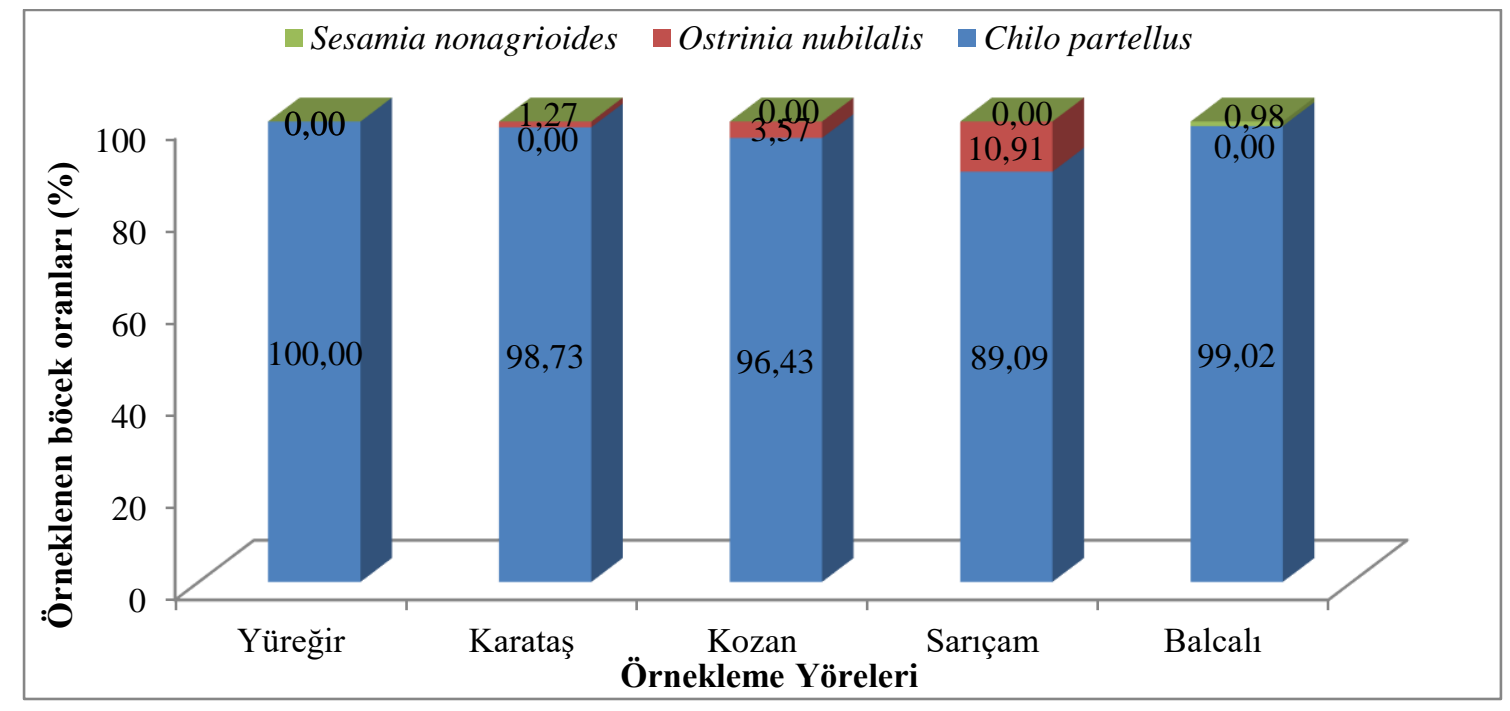

Şekil 4. Adana ilinde birinci ürün mısırlarda püskül + koçan döneminde mısır kurtlarının toplam popülasyon içinde bulunma oranları (\%). 


\section{Adana İlindeki Mısır Üretim Alanlarında Zararlı Mısır Kurtlarının (Lepidoptera: Crambidae, Noctuidae) Yaygınlık Durumunun Belirlenmesi}

\section{Adana İli İkinci Ürün Mısırlarda Zararlı Misırkurtlarının Genel Durumu}

İkinci ürün mısırlarda yapılan örneklemeler sonucunda, misır kurtları ile bulaşık bitki oranları, Balcalı ve Kozan yörelerinde sirasiyla $\% 32.36$ ve \%28.16 ile en yüksek olmuştur.
Yüreğir yöresi ise birinci ürün misırlarda olduğu gibi ikinci ürünlerde de \%5.18'lik oran ile bulaşık bitki oranının en düşük olduğu yöre olurken, Ceyhan ve Sarıçam yörelerinde ise bu oran sirasiyla \%21.04 ve \%13.27 olmuştur (Şekil 5).

İkinci Ürün Mısırlarda Bulaşık Bitki Oranı (\%)

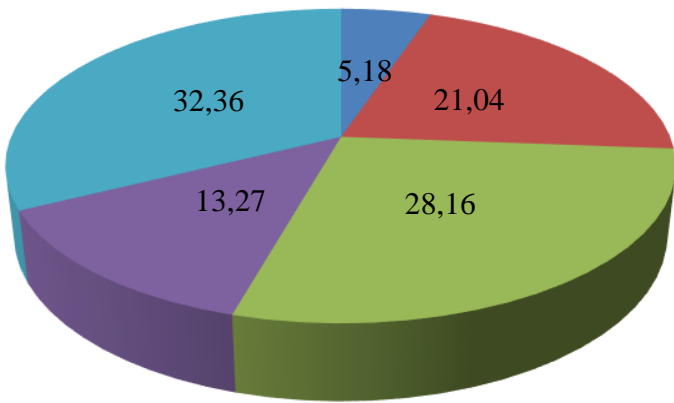

Yüreğir

Ceyhan

Kozan

Sarıçam

Balcalı

Şekil 5. Adana ilinde ikinci ürün mısırlarda yörelere göre mısır kurtları nedeniyle bitkilerde bulaşıklılık oranlar1 (\%).

Birinci ürün mısırlarda olduğu gibi ikinci ürün misırlarda da bitkilerin vejetatif ve püskül+koçan dönemlerine göre bulaşık bitki oranları incelenmiştir. Vejetatif dönemde Balcalı yöresinde örnekleme yapılan alanda tüm bitkilerin mısır kurtları ile bulaşık olduğu, diğer yörelerde ise bu oranın \%2-41 arasında değiștiği saptanmıștır (Şekil 6). Burada örnekleme yöreleri arasındaki farklılığın, yapılan kimyasal ilaç uygulamalarından kaynaklandığı düşünülmektedir. Bu bağlamda, tarım ilacı uygulanmayan Balcalı yöresinde $\% 100$ oranında bulaşıklığın olması bunu doğrulamaktadır. Bitkilerin püskül-koçan dönemine girmesiyle birlikte, Kozan, Ceyhan ve Yüreğir yörelerinde bulaşma oranlarının arttığı, Balcalı ve Sarıçam yörelerinde ise bu oranların azaldığı saptanmıştır (Şekil 6). Kozan ve Ceyhan yörelerinde meydana gelen yüksek artışın yapılan tarım ilacı uygulamalarının yetersiz ve yanlış zamanda yapılması ve ayrıca bu dönemde diğer misır kurtlarının popülasyonlarının da artış göstermesinden kaynaklandığ1 düşünülmektedir. Vejetatif dönemde bulaşıklığın en yüksek olduğu Balcalı ve Sarıçam yörelerinde ise, bitkilerin püskülkoçan dönemine girmesiyle birlikte meydana gelen düşüşün mısır kurtlarının geç ekilen ve nispeten daha sağlıklı bitkilere göç etmenlerinden kaynaklandığı düşünülmektedir.

Bölgemizde özellikle ikinci ürün misırlarda karşılaşılan en önemli zararlılar $O$. nubilalis ve $S$. nonagrioides olmasına rağmen (Kayapınar ve Kornoşor, 1992; Sertkaya ve Kornoşor, 2000), C. partellus'un da son y1llarda Adana (Balcalı)'da ikinci ürün mısırlarda önemli verim kayıplarına neden olduğu bildirilmiştir (Achiri ve ark., 2020a). Bu bağlamda, bu çalışma ile ikinci ürün mısırlarda vejetatif dönemde yapılan örneklemelerde yine $C$. partellus'un en yaygın tür olduğu ve bulaşma oranlarının Balcalı, Kozan, Ceyhan, Sarıçam ve Yüreğir yörelerinde surasiyla \%100.00, \%99.47, \%93.81, 77.27 ve 65.22 olduğu saptanmıştır. Misırkurdu, $O$. nubilalis'in ise örnekleme alanlarında vejetatif dönemde en yaygın ikinci tür olduğu ve bulaşma oranının Yüreğir'de \%34.78 ile en yüksek olduğu belirlenmiștir. Diğer yörelerde ise bu oran \%6'nın altında kalmıştır. Mısır koçankurdu, S. nonagrioides ise \%15.91'lik oran ile sadece Sarıçam yöresinde örneklenmiştir (Şekil 7). 


\section{Adana İlindeki Mısır Üretim Alanlarında Zararlı Mısır Kurtlarının (Lepidoptera: Crambidae, Noctuidae) Yaygınlık Durumunun Belirlenmesi}

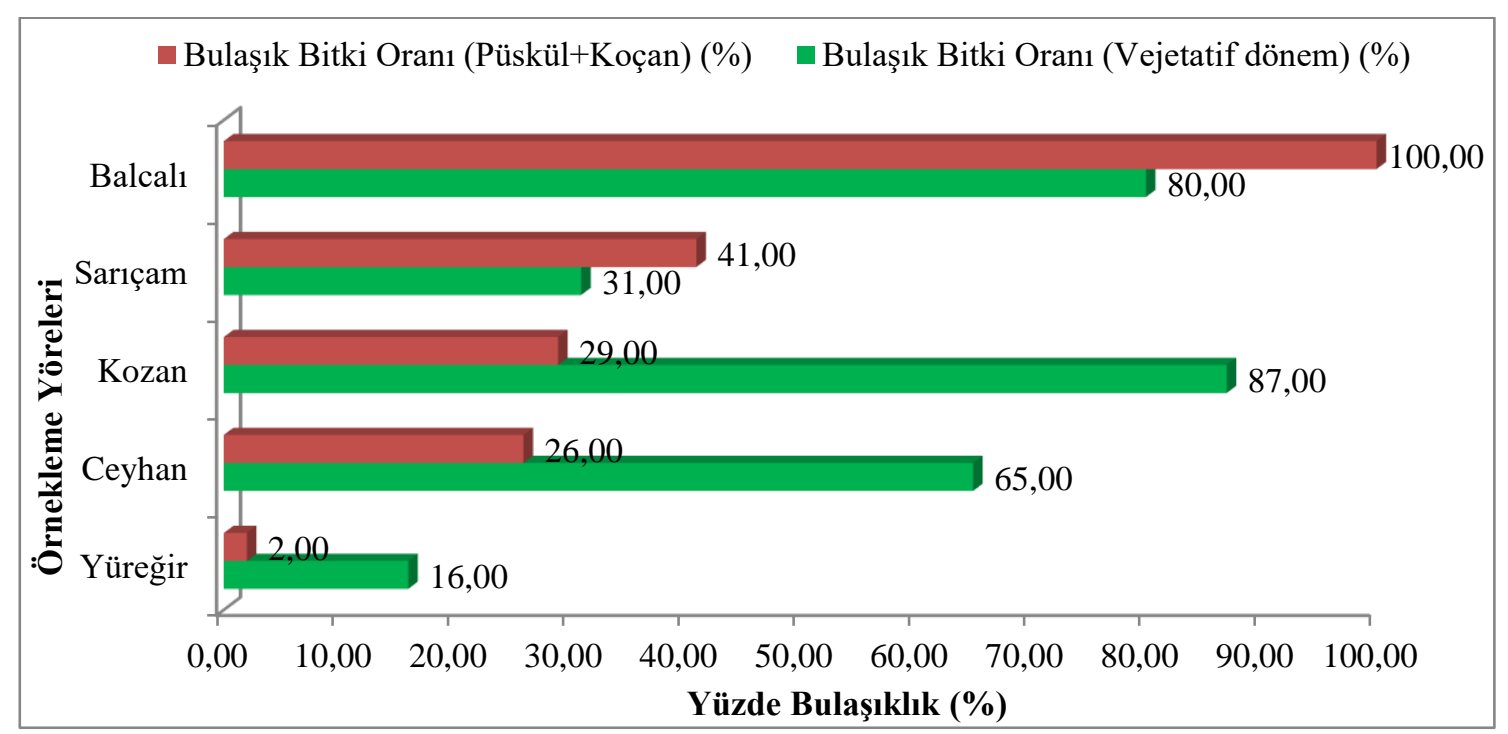

Şekil 6. Adana ilinde ikinci ürün mısırlarda örnekleme yörelerine ve bitki gelişme dönemlerine göre, mısırkurtları nedeniyle bitkilerde bulaşıklılık oranları (\%).

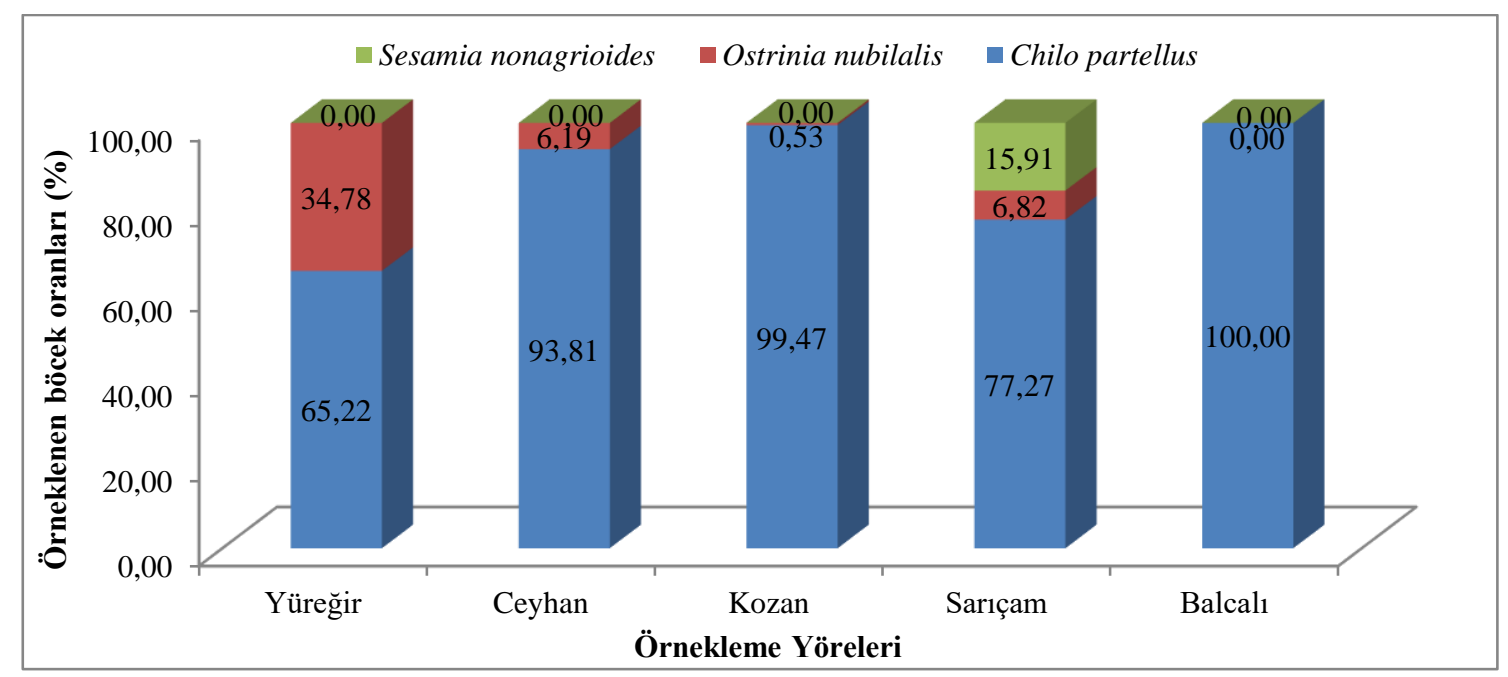

Şekil 7. Adana ilinde ikinci ürün mısırlarda vejetatif dönemde örneklenen böcek oranları (\%).

İkinci ürün mısırlarda bitkilerin püskül-koçan dönemine geçmeleriyle birlikte, Balcalı yöresi hariç, diğer tüm örnekleme alanlarında $O$. nubilalis ve $S$. nonagrioides' in bulunma oranlarında oldukça yüksek artışlar saptanmıştır. Balcalı yöresinde C. partellus $\% 94.77^{\prime} l i k$ oran ile en yaygın tür olmuştur. Diğer yörelerde ise $C$. partellus'un oranı \%10.71-50.00 arasında değişmiştir. Mısırkurdu,
O. nubilalis ise Ceyhan, Kozan ve Sarıçam yörelerinde sirasiyla \%89.29, \%77.05 ve $\%$ 63.27'lik oranlarla hakim tür olmuştur. Yüreğir bölgesinde ise $C$. partellus ve $O$. nubilalis eşit oranlarda örneklenmiştir. Mısır koçankurdu, S. nonagrioides ise Balcal1, Kozan ve Sarıçam yörelerinde \%1.29-25.51 oranlarıyla en düşük yaygınlıkta saptanmıştır (Şekil 8). 


\section{Adana İlindeki Mısır Üretim Alanlarında Zararlı Mısır Kurtlarının (Lepidoptera: Crambidae, Noctuidae) Yaygınlık Durumunun Belirlenmesi}

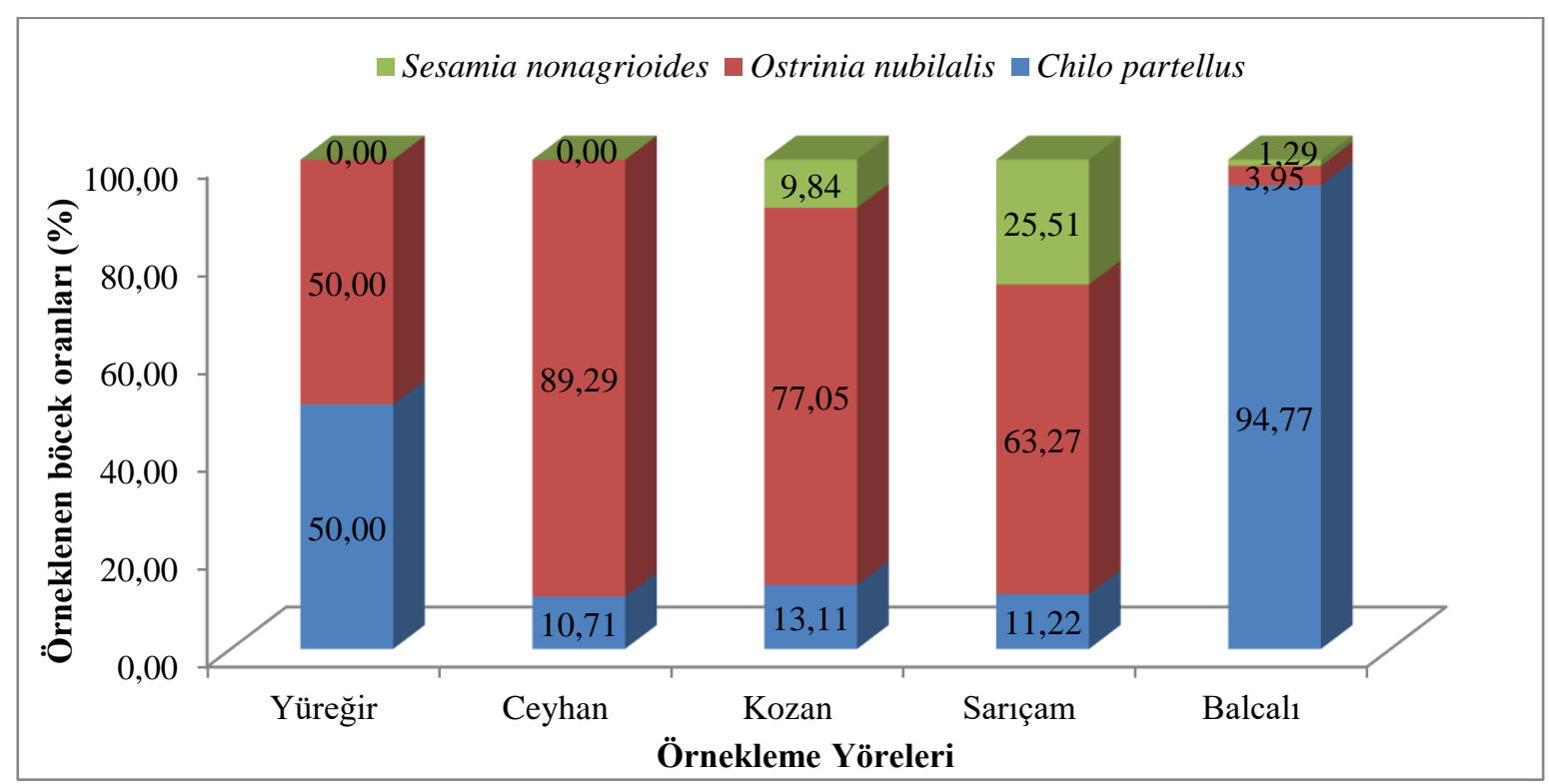

Şekil 8. Adana İlinde ikinci ürün mısırlarda püskül + koçan döneminde örneklenen mısırkurtlarının bulunma oranlar1 (\%).

İkinci ürün mısırlarda ağustos aynının başına kadar olan dönemde $C$. partellus'un tüm örnekleme yörelerinde ana zararlı tür olduğu saptanmıştır (Şekil 7). Achiri ve ark. (2020), Adana (Balcal1)'da 2018-2019 yıllarında, C. partellus'un ikinci ürün misırlarda ağustos başına kadar olan dönemde \%76-96 oranlarında bir bulaşıklılığa sebep olduğunu bildirmişlerdir. Nitekim Öztemiz ve Akmeşe (2018), bu türün Mersin ili misır alanlarında da zarar meydana getirdiğini ve Türkiye'de mısırın ana zararlıları diğer türler, $S$. nonagrioides ve $O$. nubilalis ile rekabet ederek bunların yerini alabilecek kapasitede olduğunu bildirmişlerdir. Çukurova Bölgesi'nde ikinci ürün mısırlarda yapılan diğer çalışmalarda ise mısır bitkisinin $40-50 \mathrm{~cm}$ boya geldikten sonra $O$. nubilalis popülasyonunun ortaya çıktığı, eylül ayına kadar arttığı, eylül ayından sonra ise $O$. nubilalis popülasyonunun azalıp, S. nonagrioides popülasyonunun arttığı bildirilmiştir (Kornoşor ve ark., 1995; Bayram ve Kornoşor, 1999; Kurtuluş, 2016). Bu çalışmada da $S$. nonagrioides popülasyonunun diğer iki türe oranla düşük çıkmasının en önemli sebebinin örnekleme zamanından kaynaklandığı düșünülmektedir. Bu çalıșmada örneklemeler bitkilerin kurumaya başladığı dönemde sonlandırılmıştır. Bununla birlikte, Türkiye ile aynı iklim kuşağında yer alan
Yunanistan'da $S$. nonagrioides' in birinci ürün misırlarda \% 10, ikinci ürünlerde ise \% 100'e yakın zarar oluşturduğu saptanmıştır (Tsitsipis, 1988). Bir diğer Akdeniz ülkesi olan İspanya'da ise ikinci ürün misirlarda mücadele yapılmayan misır tarlalarında $O$. nubilalis ve $S$. nonagrioides zarar1 sonucu koçanlardaki bulaşıklığın \% 82'ye ulaştığı bildirilmektedir (Malvar ve ark., 2002). Diğer misır kurtları ile yapılan tüm bu çalıșmalar $C$. partellus'un bölgemize girişinden önce yapılmış olmakla birlikte, son yıllarda Adana (Balcalı)'da yapılan çalıșmada da $C$. partellus'un birinci ürün misırlarda tüm sezon boyunca ve ikinci ürün misırlarda da Ağustos ayının ortasına kadar baskın tür olduğu tespit edilmiştir. $\mathrm{Bu}$ türün diğer türlerden daha önce diyapozdan çıkarak mısır alanlarına yerleşmesi (Kfir, 1997; Ofomata ve ark., 1999; Dejen ve ark., 2014), hızlı döl vermesi, gelişme sürelerinin daha kısa sürmesi (Dejen ve ark., 2014) ve larvalarının diğer türlere göre bitkilerde daha hızlı yayılması (Ofomata, 1997) rekabet açısından bu türe avantaj sağlamaktadır. Nitekim Ofomata ve ark. (2000), Kenya'da $C$. partellus'un yerli tür olan Chilo orichalcociliellus (Strand) (Lepidoptera: Crambidae)'yi, Güney Afrika'da ise Busseola fusca (Fuller) (Lepidoptera: Noctuidae)'yi baskılayarak ana zararlı tür olduğunu 


\section{Adana İlindeki Mısır Üretim Alanlarında Zararı Mısır Kurtlarının (Lepidoptera: Crambidae, Noctuidae) Yaygınlık Durumunun Belirlenmesi}

bildirmişlerdir (Kfir, 1997). Adana ilinde yapılan bu çalışma ile de $C$. partellus'un birinci ürün misırlarda hakim tür olduğu, ikinci ürün misırlarda da erken dönemde yerleştiği tarlalarda diğer türlerin gelişmesine firsat vermediği belirlenmiştir. $\mathrm{Bu}$ nedenle önümüzdeki yıllarda da $C$. partellus'un popülasyon gelişiminin, yaygınlığının, zarar oranının takip edilmesi ve doğal düşmanlarının belirlenmesi gerekmektedir.

\section{Teşekkür}

Bu çalışmayı FBA-2020-12624 proje numarası ile destekleyen Çukurova Üniversitesi Araştırma Projeleri Birimi'ne teşekkür ederiz.

\section{Kaynaklar}

Achiri, T. D., Atakan, E., Pehlivan, S. (2020a). Seasonal fluctuations and development of degree-day models for Chilo partellus (Lepidoptera: Crambidae) in maize fields in the Mediterranean region. Eur $J$ Entomol 117: 68-75.

Achiri, T. D., Fursov, V., Atakan, E., Pehlivan, S. (2020b). First record and parasitism of egg parasitoid Trichogramma evanescens Westwood, 1833 (Hymenoptera: Trichogrammatidae) on eggs of Chilo partellus Swinhoe, 1885 (Lepidoptera: Crambidae) in Turkey. Turk $J$ Entomol 44(1): 49-56.

Bayram, A., Kornoşor, S. (1999). Biological parameters of Trichogramma evanescens Westwood (Hymenoptera, Trichogrammatidae) on the eggs of Sesamia nonagrioides Lefebvre (Lepidoptera, Noctuidae). Procedings of the XX. Conference of the International Working Group on Ostrinia and Other Maize Pests, 165-170, 4-10 September, Adana.

Ben-Yakir, D., Chen, M., Sinev, S., Seplyarsky, V. (2013). Chilo partellus (Swinhoe) (Lepidoptera; Pyralidae), a new species in Israel. J Appl Entomol 137: 398-400.

Can Cengiz, F., Kaya, K., Ulasli, B., Moriniere, J. (2016). First record of the egg parasitoid of Chilo partellus (Swinhoe) (Lepidoptera: Crambidae) in Turkey using DNA barcoding. Turk $J$ Entomol 40(2): 125-131.
Dejen, A., Getu, E., Azerefegne, F., Ayelew, A. (2014). Distribution and impact of Busseola fusca (Fuller) (Lepidoptera: Noctuidae) and Chilo partellus (Swinhoe) (Lepidoptera: Crambidae) in Northeastern Ethiopia. $J$ Entomol Nematol 6(1): 1-13.

FAO, 2019. Food and Agriculture Organization of the United Nations Statistics. http://www.fao.org/faostat/en/\#data/QC Erişim tarihi: 20 Ocak 2021.

Güllü, D. M., Göven, D. M. A., Fidan, U. H., Aksoy, D. E., Arslan, D. Z. F. (2017). Misır Entegre Mücadele Teknik Talimatları. GTHB Matbaası, Ankara.

Guofo, Z., Overholt, W. A., Machiah, M. B. (2001). Changes in the distribution of Lepidoptera maize stem borers in Kenya from the $1950 \mathrm{~s}$ to 1990s. Int $J$ Trop Insect Sci 21: 395-402.

Kayapınar, A., Kornoşor, S. (1992). Çukurova'da Ostrinia nubilalis Hübner (Lep.: Pyralidae)'in doğal düşmanlarının saptanmas1 ve en etkilisi olan yumurta parazitoidi Trichogramma evanescens Westwood (Hym. Trichogrammatidae)'in yayılış alanının belirlenmesi. Türkiye II. Entomoloji Kongresi, 28-32 Ocak, ADANA.

Kayapınar, A. (1988). Çukurova Bölgesinde Misirlarda Zararlı Olan Misir Kurdu (Ostrinia nubilalis Hbn., Lep.;Pyralidae)'nun Biyolojisi ve Popülasyon Gelişmesi. Yüksek Lisans Tezi, Çukurova Üniversitesi.

Kfir, R. (1993). Diapause termination in the spotted stem borer Chilo partellus (Lepidoptera: Pyralidae) in the laboratory. Ann Appl Biol 123: 1-7.

Kfir, R. 1997. Natural control of the cereal stemborers Busseola fusca and Chilo partellus in South Africa. Insect Sci Appl 17:61-68.

Kornoşor, S., Coşkuntuncel, S., Sertkaya, E. (1995). Population development of egg parasitoids, Trichogramma evanescens Westwood and Platytelenomus busseolae (Gahan) on the eggs of Ostrinia nubilalis Hübner and Sesamia nonagrioides Lef. in the Southeast Mediterranean Region of 


\section{Adana İlindeki Mısır Üretim Alanlarında Zararlı Mısır Kurtlarının (Lepidoptera: Crambidae, Noctuidae) Yaygınlık Durumunun Belirlenmesi}

Turkey. Procedings of the XVIII Conference of the International Working Group on Ostrinia nubilalis, 11-16 September, 91-96.

Kurtuluş, A. (2016). Çukurova'da misır sap kurtlar1 [Ostrinia nubilalis Hübner (Lep: Crambidae), Sesamia nonagrioides Lefebvre (Lep: Noctuidea)]'na karş1 farkl1 mücadele yöntemlerinin etkinlikleri ve entegrasyonu. Doktora Tezi, Çukurova Üniversitesi.

Malvar, R. A., Revilla, P., Valesco, P., Cartea, M., Ordas, A. (2002). Insects damage to sweet corn hybrids in the South Atlantic European Coast. J Am Soc Hortic Sci 127: 693-696.

Ofomata V. C. (1997). Ecological interactions between Chilo orichalcociliellus strand and Chilo partellus (Swinhoe) (Lepidoptera: Pyralidae) on Kenya Coast. $\mathrm{PhD}$ Thesis. Nnamdi Azikiwe University. Anambra State, Nigeria. 206 pg.

Ofomata, V. C., Overholt, W. A., Egwuatu, R. I. (1999). Diapause termination of Chilo partellus (Swinhoe) and Chilo orichalcociliellus strand (Lepidoptera: Pyralidae). Insect Sci Appl 19: 187-191.

Özpınar, A., Kornoşor, S. (1997). The Studies Ostrinia nubilalis Hübner (Lepidoptera, Pyralidae) and Sesamia nonagrioides Lef. (Lep., Noctuidae) in Turkey . XIX. IWGO Conference, Portugal, 103-112.

Öztemiz, S., Akmeşe, V. (2018). Mersin İli Misır Üretim Alanlarında İstilacı Bir Zararlı: Chilo partellus (Swinhoe, 1885)(Lepidoptera: Crambidae). KSÜ Tar Doğa Derg 21(4): 489-491.

Polaszek, A. (1998). African Cereal Stem Borers: Economic Importance, Taxonomy, Natural Enemies and Control. Wallingford, UK. CABI. 530pp.

Purseglove, J. W. (1992). Tropical Crops: Moncotyledons. Longman Scientific and Technical, New York. 300-305.

Sandhu, K. S., Singh, N., Malhin, N. S. (2007). Some properties of corn grains and their flours I: Physicochemical, functional and chapatti-making properties of flours. Food Chem 101: 938-946.

Sertkaya, E., Bayram, A. (2005). Parasitoid community of the loreyi leaf worm Mythimna (Acatholeucania) loreyi: Novel host-parasitoid associations and their efficiency in the eastern Mediterranean region of Turkey. Phytoparasitica 33: 441-449.

Sertkaya, E., Kornoşor, S. (2000). Çukurova'da Misır koçankurdu, Sesamia nonagrioides Lef. (Lepidoptera: Noctuidae)'in Doğal Düşmanları. Türkiye 4. Entomoloji Kongresi, 12-15 Eylül, Aydın, 339-348.

Sertkaya, E. (1993). Çukurova'da Misır Bitkisinde Zararlı Misır Koçan Kurdu, Sesamia nonagrioides Lefebvre (Lep.:Noctuidae)'in Biyolojisi Popülasyon Gelişmesi ve Doğal Düşmanları. Yüksek Lisans Tezi, Çukurova Üniversitesi.

Sertkaya, E., Akmeşe, V., Atay, E. (2014). Türkiye'de misirda yeni bir zararl, Chilo partellus (Swinhoe) (Lepidoptera: Crambidae). Türk Entomol Bült 4(3): 197-200.

Sertkaya, E., Bayram, A., Kornosor, S. (2004). Egg and larval parasitoids of the beet armyworm Spodoptera exigua on maize in Turkey. Phytoparasitica 32: 305-312.

Tsitsipis, J. A. (1988). The Corn Stalk Borer, Sesamia nonagriodes: Forecasting, croploss assessment and pest management. Integrated Crop Protection in Cereals. Balkema, Rotterdam, Brookfield, 171177.

TUIKK, 2019. Türkiye İstatistik Kurumu, Tahıllar ve diğer bitkisel ürünlerin alan ve üretim miktarları. https://biruni.tuik.gov.tr/medas/?kn=92\& locale=tr Erişim tarihi: 20 Ocak 2021.

Yonow, T., Kriticos, D. J., Ota, N., Van den Berg, J., William, D. H. (2017). The potential global distribution of Chilo partellus, including consideration of irrigation and cropping patterns. J Pest Sci 90(2): 459-477. 